\title{
Influence of integrated crop-livestock-forest on morphological composition and nutritional value of Marandu palisadegrass under continuous grazing
}

\section{Influência da integração lavoura-pecuária-floresta na composição morfológica e valor nutricional do capim- marandu sob pastejo contínuo}

\begin{abstract}
Erikelly Aline Ribeiro de Santana ${ }^{1 *}$; Ciniro Costa2; Paulo Roberto de Lima Meirelles ${ }^{3}$; Cristiana Andrighetto ${ }^{4}$; Gustavo Pavan Mateus ${ }^{5}$; Patrícia Aparecida da Luz $^{6}$; Aline Sampaio Aranha7; Gelci Carlos Lupatini6; Cleunice Auxiliadora Fialho7; Helena Sampaio Aranha ${ }^{8}$
\end{abstract}

\section{Highlights}

ICL was the system with highest dry mass of forage, stem and dead material.

The crude protein was greater in the ICLFs.

Accumulation rate and dry mass of leaf blades did not change between systems.

Until the first year of grazing, tree systems have advantages.

\section{Abstract}

This study characterizes the changes in leaf mass, morphological composition and nutritional value of leaf blades of palisadegrass (Urochloa brizantha cv. Marandu) under continuous grazing in the first year of

1 Doctoral Scholar of Post Graduate Program in Animal Science, School of Veterinary Medicine and Animal Science, Universidade Estadual de São Paulo, UNESP, Botucatu, SP, Brazil. E-mail: erikellysantana@hotmail.com; aline. aranha@outlook.com

2 Prof. of Post Graduate Program in Animal Science, School of Veterinary Medicine and Animal Science, UNESP, Botucatu, SP, Brazil. E-mail: ciniro@fmvz.unesp.br

3 Prof. of School of Veterinary Medicine and Animal Science, UNESP, Botucatu, SP, Brazil. E-mail: paulom@fmvz.unesp.br

4 Profa of Post Graduate Program in Animal Science in Animal Science and Technology, College of Agricultural and Technological Sciences, UNESP, Dracena, SP, Brazil. E-mail: cristiana.andrighetto@unesp.br

5 Researcher in Agência Paulista de Tecnologia do Agronegócio, APTA, Andradina, SP, Brazil. E-mail: gpmateus@apta. sp.gov.br

6 Profs. of College of Agricultural and Technological Sciences, UNESP, Dracena, SP, Brazil. E-mail: patricia.luz@unesp. br; gelci.lupatini@unesp.br

7 Researcher in School of Veterinary Medicine and Animal Science, UNESP, Botucatu, SP, Brazil. E-mail: cleofialho@ yahoo.com.br

8 Undergraduate student in Post Graduate Program in Animal Science in Animal Science and Technology, College of Agricultural and Technological Sciences, UNESP, Dracena, SP, Brazil. E-mail: helena-aranha@live.com

* Author for correspondence

Received: Mar. 06, 2021 - Approved: June 09, 2021 
implementation of pasture and after second year of the eucalyptus planting in an Integrated Crop-Livestock System and Integrated Crop-Livestock-Forest, which were tested in the four seasons. The experimental design was in random blocks, with three treatments: Crop-Livestock System (ICL) and Integrated CropLivestock-Forest with two eucalyptus tree densities (ICLF-1L, 196 eucalyptus trees ha-1 and ICLF-3L, 448 eucalyptus trees $\mathrm{ha}^{-1}$ ) and four replicates. Sixty castrated Nellore cattle with initial weight of $235.43 \pm 25.46$ $\mathrm{kg}$ and mean age of $16 \pm 2.81$ months were used during the growing phase under continuous grazing. The agronomic variables were: total dry mass of forage, leaves, stem and dead material; leaf: stem and live: senescent material ratios; and accumulation rate. The leaf: stem and live: senescent material relation did not obtain any difference between the evaluated systems. Dry matter, crude protein, fiber fractions and digestibility of leaf blades were evaluated. Dry mass of the forage (6775 kg ha-1), stem (2175 kg ha-1), senescent material $\left(3175 \mathrm{~kg} \mathrm{ha}^{-1}\right)$ and dry matter content (28.6\%) were greater in the ICL, whereas crude protein $(11.3 \%)$ was greater in the ICLFs. On the other hand, accumulation rate and dry mass of leaf blades did not change between systems. Thus, until the first year of grazing, tree systems have advantages, because the forage production (accumulation rate) and leaf mass are similar to those of plants in full sun, besides showing higher nutritional value.

Key words: Morphological composition. Digestibility. Leaf: stem ratio. Urochloa brizantha.

\section{Resumo}

Este estudo caracterizou as mudanças na massa foliar, composição morfológica e valor nutricional das lâminas foliares de capim-marandu (Urochloa brizantha cv. Marandu) sob pastejo contínuo no primeiro ano de implantação da pastagem e após o segundo ano de plantio de eucalipto em Sistemas de Integração Lavoura-Pecuária e Integração Lavoura-Pecuária-Floresta, os quais foram testados nas quatro estações. O delineamento experimental foi em blocos casualizados, com três tratamentos: Integração LavouraPecuária (ILP) e Integração Lavoura-Pecuária- Floresta com duas densidades de eucaliptos (ILPF-1L, 196 árvores por ha-1 e ILPF-3L, 448 árvores por ha-1) e quatro repetições. Sessenta bovinos Nelore castrados com peso inicial de $235.43 \pm 25.46 \mathrm{~kg}$ e $16 \pm 2.81$ meses foram usados durante a fase de recria sob pastejo contínuo. As variáveis agronômicas analisadas foram: massa seca total da forragem, folhas, caule e material morto; relações folha: caule e material vivo: senescente; e taxa de acumulação. Foram avaliadas a matéria seca, proteína bruta, frações fibrosas e digestibilidade das lâminas foliares. A relação folha:caule e material vivo: senescente não obtiveram diferença entre os sistemas avaliados. A massa seca da forragem (6.775 $\left.\mathrm{kg} \mathrm{ha}^{-1}\right)$, colmo $\left(2.175 \mathrm{~kg} \mathrm{ha}^{-1}\right)$, material senescente $\left(3.175 \mathrm{~kg} \mathrm{ha}^{-1}\right)$ e teor de matéria seca (28,6\%) foram maiores no ILP, enquanto a proteína bruta $(11,3 \%)$ foi maior nos ILPFs. Por outro lado, taxa de acúmulo e massa seca das lâminas foliares não mudaram entre os sistemas. Assim, até o primeiro ano de pastejo, os sistemas arbóreos apresentam vantagens, pois a produção de forragem (taxa de acúmulo) e a massa foliar são semelhantes às das plantas a pleno sol, além de apresentarem maior valor nutricional.

Palavras-chave: Composição Morfológica. Digestibilidade. Relação folha: colmo. Urochloa brizantha. 


\section{Introduction}

Degraded pastures (i.e., low yield per area) cover approximately 80 million hectares in the Brazil (Crusciol et al., 2014). This has negative implications for livestock sustainability, such as low forage supply, low productive performance, and low meat yield per hectare, as well as low economic returns and system inefficiency (Balbino et al., 2011). In this sense, it is necessary to search for alternatives capable of recovering degraded areas, with the objective of promoting an increase of the expansion of global food production for the future (Wirsenius, Azar, \& Berndes, 2010), without deforestation of new areas, together with the urgent need for sustainable agriculture and livestock breeding. The Integrated Crop-Livestock Systems help to reverse this scenario and are considered the "new green revolution in the tropics" (Mateus, Crusciol, \& Borghi, 2012).

Among the systems, the Integrated Crop-Livestock (ICL) integrates the agricultural and livestock components in succession, consortium or rotation in the same area. Recently, the arboreal component was introduced, originating the Integrated Crop-Livestock-Forest (ICLF), with increased benefits, especially, increasing the thermal comfort index of the animals kept in the shade of the trees (Silva et al., 2011).

However, the introduction of trees into the system causes changes in the microclimate of the understory where there is the cultivation of forages. When compared to a treeless system in the summer season, ICLF system provides reduction in plant development and the crops yields cultivated between tree lines (Domingues et al., 2017;
Pezzopane et al., 2019), due competition for water and nutrients between tree and forages species and also by the different microclimatic conditions, mainly with through reduction of solar radiation compared to a treeless system (Pezzopane et al., 2015, 2019).

However, it is important to note that there are significant differences in quality and amount of solar radiation in the understory in this system due the density and tree canopy architecture (C. O. D. Rodrigues et al., 2014). Thus, the objective of the present study was to evaluate the forage mass, morphological composition of palisadegrass (Urochloa brizantha cv. Marandu) and nutritive value of these leaf blades in the first year under continuous grazing and second year after of the eucalyptus planting (Eucalyptus grandis $\times$ Eucalyptus urophylla), with a variable grazing rate in three Integrated Crop-Livestock Systems: without available shade (ICL) and at two different tree densities (196 trees ha-1, ICLF-1L and 448 trees ha ${ }^{-1}$, ICLF-3L) over a year in all climatic seasons.

\section{Material and Methods}

The experiment was carried out in accordance with the ethical principles for animal tests (Protocol No. 86/2014 - ECAU).

The experiment was carried out at the Agência Paulista de Tecnologia dos Agronegócios (APTA), located in Andradina $\left(20^{\circ} 53^{\prime} 38^{\prime \prime}\right.$ south latitude, $51^{\circ} 23^{\prime} 1^{\prime \prime}$ west longitude, and an altitude of $400 \mathrm{~m}$ ), west of São Paulo state. The predominant climate in the region is Aw according to Köppen-Geiger. Climatic data of the experimental area were collected at a meteorological station located about $2 \mathrm{~km}$ from the experimental site (Figure 
1A). Global radiation was obtained by means of daily data collected by the Três LagoasMS Automatic Station (W51S21 (E) SP) of the National Institute of Meteorology (INMET), approximately $40 \mathrm{~km}$ from Andradina city. Water balance was calculated using the mean temperature and cumulative monthly rainfall (Figure 1B).

The experiment was conceived in the first half of 2012, when specific treatments were selected, and the paddocks were divided. The soil of the experimental area was classified as Dystrophic Yellow Red Latosol V\%: pasture - 64; 1L - 51 e 3L - 56 (Empresa Brasileira de Pesquisa Agropecuária [EMBRAPA], 2013) with a sandy surface layer and a mean terrain slope of $6 \%$.

The eucalyptus clone used in the ICLF systems was I-224, which is a hybrid of Eucalyptus grandis $\times$ Eucalyptus urophylla. The trees were established by manually transplanting seedlings, following the level curves in the area, from November 2012 to March 2013. Sowing fertilization, cover fertilization, culture treatments aimed at controlling weeds, specific irrigation for newly planted trees and replanting were carried out as required.
Soybean sowing was performed in December 2012 in all systems, at a density of 20 seeds per meter and with a spacing of $0.50 \mathrm{~m}$. The mineral fertilization applied to sowing corresponded to the application of 12 $\mathrm{kg} \mathrm{ha}^{-1}$ of $\mathrm{N}, 90 \mathrm{~kg} \mathrm{ha}^{-1}$ of $\mathrm{P}_{2} \mathrm{O}_{5}$ and $48 \mathrm{~kg} \mathrm{ha}^{-1}$ of $\mathrm{K}_{2} \mathrm{O}$. Cover fertilization was conducted 40 days after sowing, applying $200 \mathrm{~kg} \mathrm{ha}^{-1}$ of the formulated 00-20-20.

After the soybean harvest, in May 2013, weed control was performed. The area was treated using glyphosate-based herbicide (Roundup WG ${ }^{\circledR}$ ) at a dose of 1440 $\mathrm{g}$ a.i.ha-1 with an application volume of 250 I ha ${ }^{-1}$. In December 2013, the grass and maize were sown together, using Urochloa brizantha (Syn. Brachiaria brizantha) cv. Marandu, in the amount of $8.0 \mathrm{~kg} \mathrm{ha}^{-1}$ of pure and viable seeds, planted with a spacing of $0.20 \mathrm{~m}$ between rows in no-tillage, and the maize (Biogene 7049 hybrid) was sown with a spacing of 0.80 $\mathrm{m}$ between rows. Fertilization used $24.8 \mathrm{~kg}$ ha-1 of $\mathrm{N}, 86.8 \mathrm{~kg} \mathrm{ha}^{-1}$ of $\mathrm{P}_{2} \mathrm{O}_{5}$ and $49.6 \mathrm{~kg} \mathrm{ha}^{-1}$ of $\mathrm{K}_{2} \mathrm{O} ; 20$ days after emergence of the maize crop, fertilization was performed with $92 \mathrm{~kg}$ $\mathrm{ha}^{-1}$ of nitrogen via urea. Maize harvesting was carried out in April 2014 

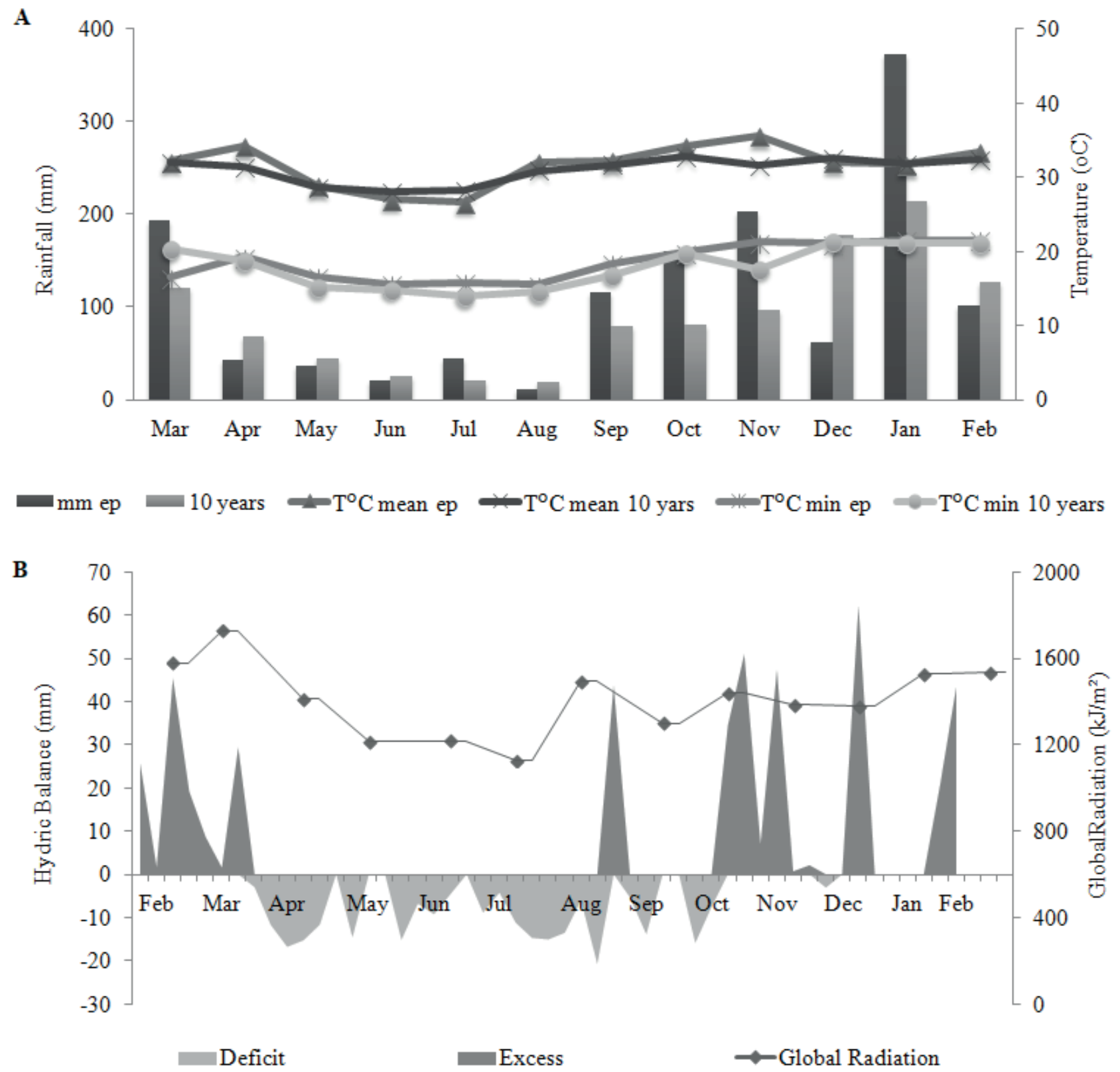

Figure 1. Temperature and rainfall means of the last 10 years and during experimental period (ep); and B) Global radiation and hycric balance for the region of Andradina, SP, (March 2015 to February 2016), Andradina-SP, Brazil. 
In October 2014, soil samples were collected from the $0-20 \mathrm{~cm}$ layer for the chemical analysis of the systems. The following results were presented: 1) ICL: $\mathrm{pH}=5.2 ; \mathrm{MO}=$ $21 \mathrm{~g} \mathrm{dm}^{-3} ; \mathrm{P}=15 \mathrm{~g} \mathrm{mg}^{-3} ; \mathrm{K}=1.28, \mathrm{Ca}=14, \mathrm{Mg}$ $=9.42, \mathrm{SB}=25 \mathrm{mmol}$ and $\left.\mathrm{dm}^{-3} ; 2\right) \mathrm{ICLF}-1 \mathrm{~L}: \mathrm{pH}$ $=4.9 ; \mathrm{MO}=20 \mathrm{~g} \mathrm{dm}^{-3} ; \mathrm{P}=9 \mathrm{~g} \mathrm{mg}^{-3} ; \mathrm{K}=1.45$, $\mathrm{Ca}=11, \mathrm{Mg}=7.45, \mathrm{SB}=20 \mathrm{mmol}$ and $\mathrm{dm}^{-3} ; 3$ ) ICLF-3L: $\mathrm{pH}=5.0 ; \mathrm{MO}=20 \mathrm{~g} \mathrm{dm}^{-3} ; \mathrm{P}=7 \mathrm{~g} \mathrm{mg}^{-}$ 3; $\mathrm{K}=1.51, \mathrm{Ca}=12, \mathrm{Mg}=9.04, \mathrm{SB}=23 \mathrm{mmol}$ and $\mathrm{dm}^{-3}, \mathrm{SB}=$ sum of bases $\left(\mathrm{Ca}^{2+}+\mathrm{Mg}^{2+}+\mathrm{K}^{+}\right)$. Liming was carried out when implementing the systems (Domingues et al., 2017). In July 2012, the area was corrected based on chemical analyzes $(0-20 \mathrm{~cm})$ of the soil that had the following attributes: $\mathrm{pH}\left(\mathrm{CaCl}_{2}\right)$ 4,8; M.O. $16 \mathrm{~g}$ $\mathrm{dm}^{-3} ; \mathrm{P}$ (resin) $3 \mathrm{mg} \mathrm{dm}^{-3} ; \mathrm{K}^{+}, \mathrm{Ca}^{2+}, \mathrm{Mg}^{2+} \mathrm{e} \mathrm{H}+\mathrm{Al}$ 1,$9 ; 7 ; 5$ e $20 \mathrm{mmol}_{\mathrm{c}} \mathrm{dm}^{-3}$, respectively, S-SO ${ }_{4}{ }^{2-}$ $1 \mathrm{mg} \mathrm{dm}^{-3} \mathrm{e} \mathrm{V \%}$ (base saturation) of 42 . The clay content; silt and sand was 107; 113 and $780 \mathrm{~g} \mathrm{~kg}^{-1}$, respectively. A dolomitic limestone (PRNT 80\%) was applied to the haul in an average amount of $1200 \mathrm{~kg} \mathrm{ha}^{-1}$ to increase saturation by bases to $70 \%$ and agricultural plaster in a total area in the amount of $600 \mathrm{~kg}$ ha-1 in order to provide sulfur to cultures, as recommended by Boletim 100 (Raij, Cantarella, Quaggio, \& Furlani, 1997) for the State of São Paulo. In soil preparation, terracing, plowing harrowing, plowing and leveling harrowing were carried out.

In December 2014, pasture standardization was performed cutting the forage mechanically at $15 \mathrm{~cm}$ from the soil using Hydraulic Cutter for RT 1400 tractor with cardan (Maqtron ${ }^{\circledR}$, Joaçaba, Brazil), followed by nitrogen fertilization of $40 \mathrm{~kg} \mathrm{ha}^{-1}$ of $\mathrm{N}$ in the form of urea. The experimental period was from March 2015 to February 2016, using the months of January and February 2015 to establish the forage canopy and for the adaptation of the animals to the systems.

During the experimental period, the trees were measured at 30 months of implantation (August 2015), presenting in the ICLF-1L system: $9.0 \mathrm{~m}$ of height and 9.6 of diameter at breast height (dbh); ICLF-3L: 9.9 $\mathrm{m}$ of height and $9.3 \mathrm{~m}$ of $\mathrm{dbh}$. The monitoring of the height conditions of the forage canopy was performed by means of a ruler graduated in centimeters $(\mathrm{cm})$, and the distance between the curvature of the highest leaf at the sampling point and the soil (Hodgson, 1990), in zig-zag at average intervals of 14 days, with an average sampling number of 100 points per experimental unit.

Sixty castrated Nellore beef cattle, with a mean weight of $235.43 \pm 25.46 \mathrm{~kg}$ and mean age of $16 \pm 2.81$ months, were used during the growing phase only to lower pasture. These animals were initially blocked by weight and age group into 12 paddocks containing the treatments (Table 1). The animals received mineral supplement with added protein and low energy consumption during the rainy period (January to April 2015 and November 2015 to April 2016), and the dry season (April to November 2015), with an intake of $0.1 \%$ of body weight. 
Table 1

Paddock and experimental area treatments, Andradina - São Paulo, Brazil

\begin{tabular}{ccc}
\hline Paddock & Area (ha) & Production system \\
\hline A & 1.88 & ICL \\
B & 1.95 & ICL \\
C & 1.81 & ICL \\
D & 2.04 & ICL \\
E & 2.75 & ICLF-3L \\
F & 2,03 & ICLF-1L \\
G & 2.12 & ICLF-1L \\
H & 1.97 & ICLF-3L \\
I & 2.33 & ICLF-1L \\
J & 2.13 & ICLF-3L \\
K & 2.39 & ICLF-1L \\
L & 2.31 & ICLF-3L \\
\hline Total & 25.71 & \\
\hline
\end{tabular}

ICL: Integration Crop-Livestock; ICLF-1L: Integration Crop-Livestock-Forest, with eucalyptus trees planted in single lines, the distance between each eucalyptus range being $17 \mathrm{~m}$ to $21 \mathrm{~m}$ and the distance between plants of $2 \mathrm{~m}$, with

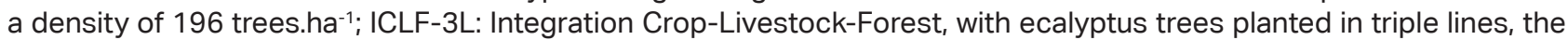
distance between the eucalyptus ranges being $17 \mathrm{~m}$ to $21 \mathrm{~m}$, the distance between plants of $2 \mathrm{~m}$ and the distance between eucalyptus lines of $3 \mathrm{~m}$, with a density of 448 trees.ha-1. $^{-1}$.

The adopted grazing method was continuous grazing with a variable grazing rate, using the put and take technique (Mott \& Lucas, 1952). In each paddock, five animal testers and a variable number of regulators were used, according to the need to adjust the grazing rate to maintain the handling goal, with a mean grass height of $30 \mathrm{~cm}$. The height conditions of the forage canopy were monitored using a centimeter graduated metric ruler (cm), at 14-day intervals.

The evaluation of the total forage accumulation used four exclusion cages of $1 \mathrm{~m}^{3}(1 \times 1 \times 1 \mathrm{~m})$ per experimental unit. The cages were allocated by means of the triple pairing technique (Moraes, 1991). The calculation of the accumulation rate (AR) was performed using the agronomic difference method, in which the forage accumulation inside the exclusion cage was observed for a period of 28 days, according to the equation $\mathrm{AR}=\mathrm{FMf}-\mathrm{FMi}$, where: $\mathrm{AR}$ : forage accumulation rate; $F M f=$ forage mass under the cage, on the last day of the exclusion (day 28) and FMi = average forage mass in the experimental unit on the day of the cage allocation (day 0). The result was expressed in $\mathrm{kg} \mathrm{ha}^{-1}$ day $^{-1}$.

Forage evaluations were performed every 28 days in all experimental units. For the measurement of the total dry mass of forage (TDM), it was used a metallic frame $1 \times 0.5 \mathrm{~m}$ $\left(0.5 \mathrm{~m}^{2}\right)$ to measures the area of the sample 
collection. All material inside the quadrat was cut at the ground level, at nine sampling points from each plot, totaling $4.5 \mathrm{~m}^{2}$, in locations that were representative of all the pasture, regardless of the distance to the trees, provided that it represents the total pasture of the evaluated system. The cut forage was weighed, homogenized and two subsamples were then extracted.

The first sub-sample was weighed and placed in the forced air circulation oven to determine the dry matter at $60^{\circ} \mathrm{C}$ until a constant weight was reached. The second sub-sample was used to determine the morphological composition, performed by manual sorting of the following plant components: leaf blade, considering the blades with less than $50 \%$ senescent tissue, plus growing leaves; stem: stem and sheath of tiller that had or did not have inflorescence; senescent material: necrosed or senescent tissue covering more than $50 \%$ of its leaf extension adhered to the tiller and the completely necrotic material not adhered to the tiller. These components were weighed and dried in a forced air circulation oven to determine the dry mass of leaf blades (DML), dry mass of stem (DMS) and dry mass of dead and senescent material (DMD). After drying, the samples were again weighed to determine the partially dried matter of the total forage and their constituents, and the proportion of each fraction was expressed in $\mathrm{kg} \mathrm{ha}^{-1}$.

The leaf:stem ratio (L:S) was calculated by the ratio between the dry mass of the leaf blades and stem, obtained by the morphological separation of the samples. The live:senescent material ratio (green material and dead material (G:D) ratio) was obtained by the ratio between the mass of green leaves and stem and the senescent material.
The dried samples of leaf blades were ground in a Willey-type mill with a 1-mm mesh to evaluate their botanical composition. The samples were returned to the oven at $105^{\circ} \mathrm{C}$ for 12 hours to determine the dry matter (DM) contents. Crude protein (CP) analyses were performed according to methodology described by the Association of Official Analytical Chemistry [AOAC] (1995). The determination of the neutral detergent fiber (NDF), acid detergent fiber (ADF) and lignin (LIG) contents followed the methodology described by Van Soest, Robertson and Lewis (1991), adapted by Mertens (2002). Hemicellulose (HEMI) was obtained by the difference between the contents of NDF and ADF and cellulose (CEL), according to the AOAC (1995). In vitro dry matter digestibility (IVDMD) was determined according to the technique described by Tilley and Terry (1963), adapted to the artificial rumen (DAISY), developed by $\mathrm{ANKOM}^{\circledR}$, according to the methodology described by Holden (1999).

The experimental design was arranged in random blocks (Table 1). Data were divided into seasons of the year, with three cycles per season considered measures repeated in time. The autumn season corresponded to the period from March to May 2015, the winter season from June to August 2015, the spring season from September to November 2015 and the summer season from December 2015 to February 2016.

The data were initially tested for normality using a Shapiro-Wilk test in SAS (SAS Inst. Inc., Cary, NC, USA), and the results indicated a normal distribution ( $\mathrm{W}>0.90)$. In the data analysis, plot was considered an experimental unit for all the characteristics under study. The data were then analyzed using the PROC MIXED procedure of SAS (Statistical 
Analysis System Institute [SAS Institute], 2010) and the Satterthwaite approach to determine the degrees of freedom for the fixed effects tests. The resulting system, block and seasons and interactions (system $\times$ season) were considered fixed effects. Plot was considered a random variable. The means were calculated by the LSMEANS procedure and the results are reported as least squares and separated using the probabilities difference (pdiff) option. Statistically significant effects were considered at $\mathrm{P}<0.05$.

\section{Results and Discussion}

For data presentation, when not the system $\times$ season interaction effect occurred, the isolated effects were considered. Only the in vitro dry matter digestibility variable presented system $\times$ season interaction $(P<0.05)$.

The AR did not differ between the systems evaluated (ICL: 52.18; ICLF-1L: 52.91; ICLF-3L: 51.21; P>0.05; Table 2). Generally, the increase of the level of shading can affect the growth and, consequently, the accumulation rate of most tropical grasses (Baruch \& Guenni, 2007; Paciulloetal.,2007). Thisoccursduetothe reduction in the luminosity available to forages growing under the treetops, a condition that influences the nutritive value of the forage and the morphogenetic aspects that determine productivity (Castro, Garcia, Carvalho, \& Couto, 1999). However, the absence of difference between the systems suggested that this was due to the phenotypic adjustments that the plant develops in response to shading, which allocate less biomass on roots and more on stems and leaves compared to plants grown in the sun (Dias, 2000; Paciullo et al., 2011), compensating their productivity in relation to ICL treatment.

This fact can be further confirmed by the absence of difference among treatments in DML ( $P>0.05$; Table 2). This is because the accumulation rate directly represents the amount of forage produced and removed by the animals, which consumes the top that is presents the most nutrition value of forage (leaves).

Another forage adaptation in shaded systems is stem elongation to prioritize leaf blade exposure to better light conditions (Paciullo et al., 2011), which may also have contributed to higher AR in these systems. However, in the present study this grass adaptation did not influence the DMS in the shaded systems, possibly because it was made from TDM samples and not from AR (Table 2). This is because TDM is evaluated by what was left in the field after grazing and not as an increase in biomass over a period of time, as is defined the AR.

Thereby, the higher DMS found in the ICL system contributed to the higher TDM in this system $(P<0.05)$. The increase in DMS may be explained by the higher tiller density in grasses under direct solar radiation (Paciullo et al., 2007). In the tree-based systems, the microclimate created in subforests provided better environmental conditions for plants during periods of climate stress (Pezzopane et al., 2015), which possibly contributed to lower DMD, justifying the higher TDM in the ICL system $(\mathrm{P}<0.05$; Table 2$)$. 
Table 2

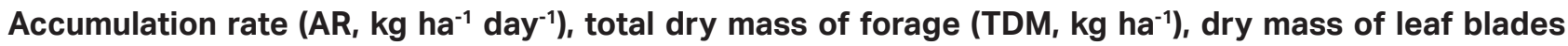
(DML, kg ha-1), dry mass of stem (DMS, $\left.\mathrm{kg} \mathrm{ha}^{-1}\right)$, dry mass of dead and senescent material (DMD, $\left.\mathrm{kg} \mathrm{ha}^{-1}\right)$, leaf:stem ratio (L:S) and green material and dead material ratio (G:D) of Marandu palisadegrass in croplivestock integration (ICL), crop-livestock-forest integration with density of 196 trees ha ${ }^{-1}$ (ICLF-1L) and crop-livestock-forest integration systems (CLFI) with density 448 trees ha-1 (ICLF-3L) in the seasons summer, autumn, winter and spring of March 2015 to February 2016

\begin{tabular}{|c|c|c|c|c|c|c|c|}
\hline \multicolumn{8}{|c|}{ System } \\
\hline & AR & TDM & DML & DMS & DMD & L:S & G:D \\
\hline ICL & 52.18 & 6775 a & 1225 & $2175 a$ & 3375 a & 0.56 & 1.35 \\
\hline ICLF-1L & 52.91 & 5792 b & 1139 & 1962 b & 2691 b & 0.58 & 1.55 \\
\hline ICLF-3L & 51.21 & 5838 b & 1166 & 1873 b & 2799 b & 0.62 & 1.48 \\
\hline \multicolumn{8}{|c|}{ Season } \\
\hline Autumn & 69.68 a & $6200 \mathrm{~b}$ & 1563 a & $2653 a$ & $1984 \mathrm{c}$ & $0.59 a$ & $2.85 a$ \\
\hline Winter & $39.85 b$ & $6760 \mathrm{a}$ & 1024 b & $2268 \mathrm{~b}$ & 3468 a & $0.45 b$ & $1.07 \mathrm{~b}$ \\
\hline Spring & $52.58 b$ & $6223 b$ & 1011 b & $1463 \mathrm{c}$ & $3749 a$ & $0.69 a$ & $0.76 \mathrm{c}$ \\
\hline Summer & $46.38 \mathrm{~b}$ & 5352 c & 1108 b & $1625 \mathrm{c}$ & $2619 b$ & $0.68 a$ & $1.16 \mathrm{~b}$ \\
\hline \multicolumn{8}{|c|}{ Statistical significance } \\
\hline System & 0.9719 & $<0.0001$ & 0.2802 & 0.0093 & $<0.0001$ & 0.3216 & 0.0763 \\
\hline Season & $<0.0056$ & $<0.0001$ & $<0.0001$ & $<0.0001$ & $<0.0001$ & $<0.0001$ & $<0.0001$ \\
\hline System $\times$ Season & 0.3630 & 0.8154 & 0.2200 & 0.0744 & 0.2736 & 0.1879 & 0.8931 \\
\hline SEM $^{1}$ & 2.37 & 75.32 & 20.85 & 39.56 & 63.82 & 0.01 & 0.0630 \\
\hline
\end{tabular}

${ }^{1} \mathrm{SEM}=$ Standard error of the mean. Equal letters do not differ by Student's t-test $(P<0.05)$.

Between seasons, the highest TDM was observed in winter and the lowest in summer. The atypical weather conditions for the region in early autumn, with high rainfall (Figure 1A), favored an increase in TDM during this season. The reproductive phase of marandu palisadegrass occurred during this period, with increasing proportion of the biomass from inflorescences and stabilization of forage (Table 2). During the winter season, stocking rate was reduced to maintain canopy height. Although water balance became positive in spring and this continued into summer, TDM was lower in summer, likely due to increased stocking rate used to maintain canopy height (canopy height $=30 \mathrm{~cm}$; stocking rates: $\mathrm{ICL}=$ 2.23 UA/ha, ICLF-1L = 2.14 UA/ha, ICLF-3L = $1.53 \mathrm{UA} / \mathrm{ha}$ ).

The DML in autumn was about $50 \%$ greater $(P<0.05)$ than in other seasons, which not differ (Table 2). This likely was due to the better growing conditions (greater temperature and precipitation) during this season (Figure 1). In winter, the leaf elongation rate was reduced during the critical period of development for the forage plants, since it occurs in conditions of milder temperatures, water deficiency and reduced light (Figure 1). The DML production in spring and summer, despite climatic conditions and high rainfall, 
which is favorable to forage development, was prejudiced by the non-restoration of nitrogen to the systems (Corsi, 1994).

The same behavior was observed for the variable AR, which obtained higher amounts in the autumn, also favored by the high temperatures and rainfall, which stimulated the grass development (Figure 1). In a study by Calvano et al. (2011) evaluating the AR at different grazing intensities at a location close to that of the present study, found that the largest variations were due to seasons instead of the grazing intensity.

Regarding DMS in the autumn, it was observed a higher amount of this variable $(P<0.05)$, followed by winter, spring and summer, which did not differ $(P>0.05)$. The rainfall and high temperature climatic factors in the transition period between the rainy and dry seasons, contributed to the increase of tillering and the emergence of inflorescences in autumn, increasing the DMS during this season, corresponding to $43 \%$ of the TDM. Part of this result was reflected in winter, but the natural disappearance of reproductive and vegetative tillers reduced the proportion of TDM to $34 \%$. The lower DMS in spring and summer is related to the reduction in TDM during these periods.

Dry mass of dead was lower in autumn and greater in winter and spring, representing $32 \%, 51 \%$ and $60 \%$ of the TDM, respectively. Under reduced rainfall, radiation and milder temperatures (Figure 1), there is a reduced emergence rate of green material, reducing the grazing rate to maintain the management height. Thus, reduced grazing in periods that are unfavorable to the regrowth of the grass resulted in low utilization of the available forage, increasing the DMD.
The L:S ratio did not differ between the systems, as this variable is more associated with the seasons of the year, as well as the G:D ratio and AR ( $P>0.05$; Table 2). On the other hand, the lowest L:S ratio occurred during winter due to climatic conditions that were detrimental to the appearance of new tillers and leaf blades. The higher DML and DMS and lower DMD in the fall resulted in a higher $G: D$ ratio during this season. Reduced DMS participation in the spring and a carryover of the DMD from winter into spring resulted in lower $\mathrm{G}: \mathrm{D}$ ratio in this period.

The DM content differed between the systems and between the season, with the highest DM levels found in the ICL, while the ICLF systems did not differ ( $P>0.05$; Table 3 ). This can be attributed to the lower transpiration rates of the plants, resulting in a higher water concentration in the tissues in shaded environments (Volenec \& Nelson, 2003). The DM contents of the leaf blades were higher in the spring, followed by winter, summer and autumn. These results are probably due to the increase in the leaf appearance rates in the spring and summer, with better rainfall distribution during this season, while the higher DM content in winter is due to the reduction of leaf appearance due to climatic conditions, which contributed to the increase of DM.

Crude protein content was lower in the ICL than in the shaded systems $(P<0.05$; Table 3). Under shade, the forage responds to increase nutritive value, like $\mathrm{CP}$, which is consistent with results in the literature (Geremia et al., 2018; Pezzopane et al., 2019). Shaded plants develop slowly compared to plants under full sunlight, and thus they can be considered physiologically younger, which may have also contributed to increased CP concentration (Paciullo et al., 2011). Another 
explanation for the higher $\mathrm{CP}$ content in shaded plants is the increased contribution of nutrients through the nutrient cycle (Paciullo et al., 2007). According to Wilson (1996), the higher soil moisture content and the lower temperatures observed in shaded environments may contribute to the higher mineralization of nitrogen and a higher cycling rate, resulting in higher $\mathrm{N}$ availability and $\mathrm{a}$ higher CP content in these plants. Moreover, the CP content was higher in the winter and spring, and lower in the summer. This may possibly be due to the lower temperatures of the winter season, reducing the development rate of the plant, thus causing a greater accumulation of reserves (O. Rodrigues et al., 2012) and lower rates of cell wall development.

\section{Table 3}

Concentration \% of dry matter (DM), crude protein (CP), neutral detergent fiber (NDF), acid detergent fiber (ADF), cellulose (CEL), hemicellulose (HEMI), lignin (LIG) and in vitro dry matter digestibility (IVDMD) of leaf Marandu palisadegrass in crop-livestock integration (ICL), crop-livestock-forest integration with density of 196 trees ha-1 (ICLF-1L) and crop-livestock-forest integration systems with density 448 trees ha $^{-1}$ (ICLF-3L) in the seasons summer, autumn, winter and spring of March 2015 to February 2016

\begin{tabular}{ccccccccc} 
& DM & CP & NDF & ADF & CEL & HEMI & LIG & IVDMD \\
\hline ICL & $28.6 \mathrm{a}$ & $9.8 \mathrm{~b}$ & 72.1 & 34.4 & 28.6 & 36.7 & 5.4 & $56.0 \mathrm{~b}$ \\
ICLF-1L & $27.1 \mathrm{~b}$ & $11.4 \mathrm{a}$ & 71.7 & 35.2 & 28.0 & 36.6 & 5.6 & $59.2 \mathrm{a}$ \\
ICLF-3L & $27.3 \mathrm{~b}$ & $11.1 \mathrm{a}$ & 71.4 & 34.9 & 27.8 & 36.6 & 5.4 & $58.8 \mathrm{a}$ \\
& \multicolumn{7}{c}{ Season } \\
Autumn & $24.7 \mathrm{~d}$ & $10.5 \mathrm{~b}$ & $74.9 \mathrm{a}$ & $35.6 \mathrm{a}$ & $25.4 \mathrm{c}$ & $39.4 \mathrm{a}$ & $5.2 \mathrm{~b}$ & $53.4 \mathrm{~d}$ \\
Winter & $28.9 \mathrm{~b}$ & $11.1 \mathrm{a}$ & $69.8 \mathrm{c}$ & $34.7 \mathrm{~b}$ & $28.7 \mathrm{~b}$ & $35.1 \mathrm{c}$ & $5.8 \mathrm{a}$ & $55.2 \mathrm{c}$ \\
Spring & $30.9 \mathrm{a}$ & $11.6 \mathrm{a}$ & $70.0 \mathrm{c}$ & $34.6 \mathrm{~b}$ & $28.7 \mathrm{~b}$ & $35.4 \mathrm{c}$ & $5.6 \mathrm{ab}$ & $64.2 \mathrm{a}$ \\
Summer & $26.2 \mathrm{c}$ & $9.9 \mathrm{c}$ & $72.3 \mathrm{~b}$ & $35.3 \mathrm{a}$ & $30.3 \mathrm{a}$ & $36.7 \mathrm{~b}$ & $5.2 \mathrm{~b}$ & $59.22 \mathrm{~b}$ \\
& & Statistical significance & & & & \\
System & 0.0153 & $<0.0001$ & 0.4369 & 0.1766 & 0.0522 & 0.9343 & 0.3557 & $<0.0001$ \\
Season & $<0.0001$ & $<0.0001$ & $<0.0001$ & 0.0060 & $<0.0001$ & $<0.0001$ & 0.0474 & $<0.0001$ \\
System $\times$ Season & 0.6311 & 0.4461 & 0.7236 & 0.1213 & 0.5874 & 0.9971 & 0.5784 & 0.0002 \\
SEM & 0.32 & 0.12 & 0.33 & 0.15 & 0.16 & 0.66 & 0.18 & 0.52
\end{tabular}

${ }^{1} \mathrm{SEM}=$ Standard error of the mean. Equal letters do not differ by Student's t-test $(\mathrm{P}<0.05)$.

The systems did not affect the NDF, ADF, CEL, HEMI and LIG ( $P>0.05)$. However, there was a difference between the seasons for all the mentioned variables $(P<0.05$; Table 3). The highest NDF content in autumn is attributed to the water balance (Figure 1), favorable to the development of plants, allowing them to reach greater heights during this season. In the winter and spring, the NDF content was reduced due to the reduced leaf expansion caused by low humidity and lower ambient temperatures. However, spring is considered a transition period between the dry and rainy seasons, and NDF levels can be 
diluted between seasonal evaluations. In the summer season, with increasing rainfall and a positive water balance (Figure 1B), the NDF content was higher than previous seasons because it provided greater turgor within the cells; increasing the turgor pressure is one of the mechanisms responsible for the increase of NDF, in order to prevent the rupture of the plant cell (Nascimento, Vilela, Sousa, \& Silveira, 2013). Similar seasonal differences in leaf blade ADF concentrations were observed, with the lowest levels in winter and spring.

Because it is also a constituent of the cell wall, the lower CEL content observed in the winter season may be related to the slower growth rate of leaf blades (lower rates of cell expansion). The greatest HEMI content occurred in autumn and the lowest in winter and spring. Climatic conditions (temperature and humidity) in the seasons of winter and spring, possibly, did not favor the thickening of the cell wall of the plant tissue during the development of the plants, reducing the HEMI content in these seasons (Taiz \& Zeiger, 2013).
There was a season and system interaction for IVDMD ( $\mathrm{P}<0.05$; Figure 2$)$, with greater IVDMD observed during the spring in all systems, not differing from the summer in the ICL. Among the systems, differences in IVDMD were found only in autumn and spring; in the autumn, in the highest tree density system (ICLF-3L), the IVDMD was higher, whereas in the ICL, it was lower. In the spring, the ICLFs did not differ; they were higher than the ICL. The winter and spring seasons were the periods with higher CP content and lower fiber contents (Table 3); however, they presented different IVDMD. The autumn season showed lower IVDMD in all systems, due to the higher fiber content during this season. Soil moisture conditions (Figure 1) in the tree systems in the rainy-dry and dry-rainy transition seasons enabled the forage to become greener during this period, improving its IVDMD. The current literature has inconsistent responses to the effect of shading on IVDMD, which may vary with different factors influencing forage composition (Castro, Paciullo, Gomide, Müller, \& Nascimento, 2009).

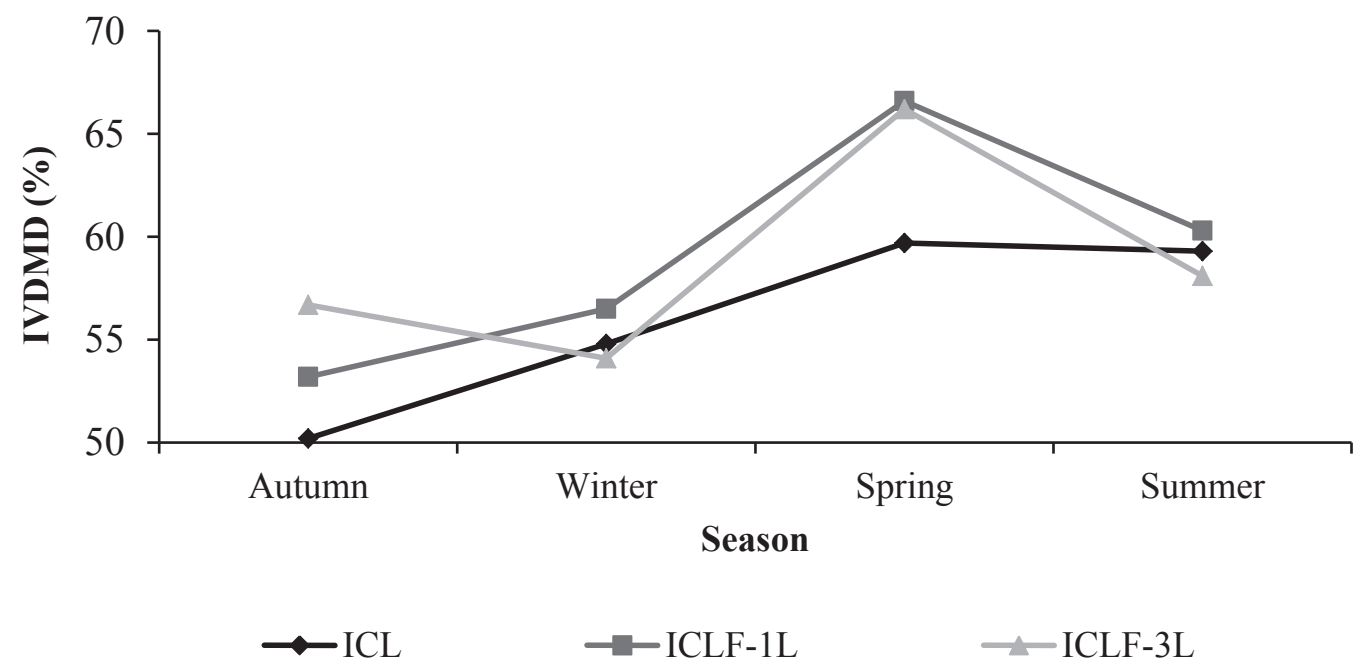

Figure 2. In vitro dry matter digestibility (IVDMD) of palisadegrass in crop-livestock integration

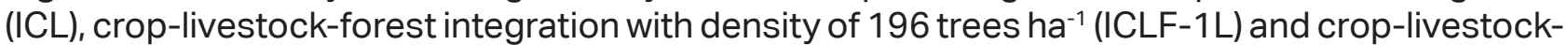

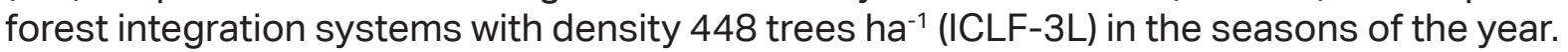




\section{Conclusion}

Although forage mass is reduced by shading, the sward productivity, indicated by accumulation rate, is not affected in systems with 196 and 448 eucalyptus ha-1, moreover systems are morphologically similar to each other.

The density of the trees does not change the botanical composition of marandu palisadegrass. On the other hand, the shading condition reduces the dry matter content, but increases the leaf blade crude protein content up to the first year in continuous grazing and after second year of the eucalyptus planting. Thus, in this period, the trees have advantages, because the productivity and leaf mass of pasture are similar to plants in full sun, besides having greater nutritional value.

\section{Acknowledgment}

APTA, Polo Regional Extreme West - Andradina/SP. To the Coordination for the Improvement of Higher Education Personnel CAPES for the scholarship.

\section{References}

Association of Official Analytical Chemistry (1995). Official methods of analysis (15nd ed.). Washington, DC.: AOAC.

Balbino, L.C., Cordeiro, L.A.M.,Porfírio-da-Silva, V., Moraes, A., Martínez, G. B., Alvarenga, R. C.,... Galerani, P. R. (2011). Evolução tecnológica e arranjos produtivos de sistemas de integração lavoura-pecuáriafloresta no Brasil. Pesquisa Agropecuária Brasileira, 46(10), 1-12. doi: 10.1590/S01 00-204X2011001000001
Baruch, Z., \& Guenni, O. (2007). Irradiance and defoliation effects in three species of the forage grass Brachiaria. Tropical Grasslands, 41(4), 269-276.

Calvano, M. P. C. A., Euclides, V. P. B., Montagner, D. B., Lempp, B., Difante, G. S., Flores, R. S. \& Galbeiro, S. (2011). Tillering and forage accumulation in Marandu grass under different grazing intensities. Revista Ceres, 58(6), 781-789. doi: 10.1590/S00 34-737X2011000600015

Castro, C. R. T., Garcia, R., Carvalho, M. M., \& Couto, L. (1999). Produção forrageira de gramíneas cultivadas sob luminosidade reduzida. Revista Brasileira de Zootecnia, 28(5), 919-927. doi: 10.1590/S1516-359 81999000500003

Castro, C. R. T., Paciullo, D. S. C., Gomide, C. A. M., Müller, M. D., \& Nascimento, E. R., Jr. (2009). Características agronômicas, massa de forragem e valor nutritivo de Brachiaria decumbens em sistema silvipastoril. Pesquisa Florestal Brasileira, 60, 19-25. doi: 10.4336/2012.pfb.60.19

Corsi, M. (1994). Adubação nitrogenada das pastagens. In A. M. Peixoto, J. C. Moura, \& V. P. Faria (Eds.), Pastagens: fundamentos da exploração racional (2a ed., pp. 121155). Piracicaba: FEALQ.

Crusciol, C. A. C., Nascente, A. S., Mateus, G. P., Pariz, C. M., Martins, P. O., \& Borghi, E. (2014). Intercropping soybean and palisade grass for enhanced land use efficiency and revenue in a no till system. European Journal of Agronomy, 58, 5362. doi: 10.1016/j.eja.2014.05.001

Dias, M., Fo. (2000). Growth and biomass allocation of the $\mathrm{C} 4$ grasses Brachiaria brizantha and $B$. humidicola under shade. Pesquisa Agropecuária Brasileira, 
35(12), 2335-2341. doi: 10.1590/S0100204X2000001200003

Domingues, M. S., Andrighetto, C., Lupatini, G. C., Mateus, G. P., Aranha, A. S., Ono, R. K.,... Sekiya, B. M. S. (2017). Growth and yield of corn forage intercropped with marandu grass in an agrosilvopastoral system with eucalyptus. Semina: Ciêncas Agrárias, 38(6), 3669-3680. doi: 10.5433/1679-0359.2017v38n6p3669

Empresa Brasileira de Pesquisa Agropecuária (2013). Sistema brasileiro de classificação de solos (3a ed.). Rio de Janeiro: EMBRAPA Solos.

Geremia, E. V., Crestani, S., Mascheroni, J. D. C., Carnevalli, R. A., Mourão, G. B., \& Silva, S. C. (2018). Sward structure and herbage intake of Brachiaria brizantha cv. Piatã in a crop-livestock-forestry integration area. Livestock Science, 212, 83-92. doi: 10.10 16/j.livsci.2018.03.020

Hodgson, J. (1990). Grazing management: science practice. Essex: Longman Scientific \& Technical.

Holden, L. A. (1999). Comparison of methods of in vitro matter digestibility for ten feeds. Journal of Dairy Science, 82(8), 1791-1794. doi: 10.3168/jds.S0022-03 02(99)75409-3

Mateus, G. P., Crusciol, C. A. C., \& Borghi, E. (2012). Integrated crop-livestock: the new green revolution in the tropics. Pesquisa Tecnológica, 4, 1-5.

Mertens, D. R. (2002). Gravimetric determination of amylase-treated neutral detergent fiber in feeds with refluxing in beakers or crucibles: collaborative study. Journal of AOAC International, 85(6), 1217-1240.
Moraes, A. (1991). Produtividade animal e dinâmica de uma pastagem de pangola (Digitaria decumbens Stent), azevém (Lolium multiflorum Lam.) e trevo branco (Trifolium repens L.), submetida a diferentes pressões de pastejo. Tese de doutorado, Universidade Federal do Rio Grande do Sul, Porto Alegre, RS, Brasil. Recuperado de http://www. bibliotecadigital.ufrgs.br

Mott, G. O., \& Lucas, H. L. (1952). The design, conduct, and interpretation of grazing trials on cultivated and improved pastures. Proceedings of the International Grassland Congress, State College Press: Philadelphia, PA, USA.

Nascimento, D., Jr., Vilela, H. H., Sousa, B. M. L., \& Silveira, M. C. T. (2013). Fatores que afetam a qualidade de plantas forrageiras. In R. A. Reis, T. F. Bernardes, \& G. R. Siqueira (Eds.), Forragicultura: ciência, tecnologia e gestão de recursos forrageiros (pp. 409424). Jaboticabal: M. de L. Brandel-ME.

Paciullo, D. S. C., Carvalho, C. A. B., Aroeira, L. J. M., Morenz, M. J. F., Lopes, F. C. F., \& Rossiello, R. O. P. (2007). Morfofisiologia e valor nutritivo do capim-braquiária sob sombreamento natural e a sol pleno. Pesquisa Agropecuária Brasileira, 42(4), 573-579. doi: 10.1590/S0100-204X2007 000400016

Paciullo, D. S. C., Gomide, C. A. M., Castro, C. R. T., Fernandes, P. B., Müller, M. D., Pires, M. F. A.,... Xavier, D. F. (2011). Características produtivas e nutricionais do pasto em sistema agrossilvipastoril, conforme a distância das árvores. Pesquisa Agropecuária Brasileira, 46(10), 11761183. doi: 10.15 90/S0100-204X201100 1000009 
Pezzopane, J. R. M., Bernardi, A. C. C., Bosi, C., Oliveira, P. P. A., Marconato, M. H., Pedroso, A. F., \& Esteves, S. N. (2019). Forage productivity and nutritive value during pasture renovation in integrated systems. Agroforestry Systems, 93, 3949. doi: 10.1007/s10457-017-0149-7

Pezzopane, J. R. M., Bosi, C., Nicodemo, M. L. F., Santos, P. M., Cruz, P. G., \& Parmejiani, R. S. (2015). Microclimate and soil moisture in a silvopastoral system in southeastern Brazil. Bragantia, 74(1), 110-119. doi: 10. 1590/1678-4499.0334

Raij, B. van, Cantarella, H., Quaggio, J. A., Furlani, A. M. C. (Eds.). (1997). Recomendações de adubação e calagem para o Estado de São Paulo. (IAC. Boletim Técnico, 100). Campinas: Instituto Agronômico de Campinas.

Rodrigues, C. O. D., Araújo, S. A. C., Viana, M. C. M., Rocha, N. S., Braz, T. G. S., \& Villela, S. D. J. (2014). Light relations and performance of signal grass in silvopastoral system. Acta Scientiarum. Animal Sciences, 36(2), 129-136. doi: 10.4025/actascianimsci.v3 $6 \mathrm{i} 2.22398$

Rodrigues, O., Fontanelli, R. S., Costenaro, E. R., Marchese, J. A., Scortganha, A. C. N., Saccardo, E., \& Piasecki, C. (2012). Bases fisiológicas para o manejo de forrageiras. In R. S. Fontanelli, \& H. P. Santos (Eds.), Forrageiras para integração lavourapecuária-floresta na região sul-brasileira (2a ed., pp. 59-125). Brasília: Embrapa.

Silva, J. A. R., Araújo, A. A., Lourenço, J. B., Jr., Santos, N. F. A., Garcia, A. R., \& Nahúm, B. S. (2011). Conforto térmico de búfalas em sistema silvipastoril na Amazônia Oriental. Pesquisa Agropecuária Brasileira, 46(10),
1364-1371. doi: 10.1590/S0100-204X20 11001000033

Statistical Analysis System Institute (2010). SAS User's guide: statistics. Version 9.3. Cary, NC: SAS Institute.

Taiz, L., \& Zeiger, E. (2013). Fisiologia vegetal (5a ed.). Porto Alegre: Artmed.

Tilley, J. M. A., \& Terry, R. A. (1963). A two stage technique for the in vitro digestion of forage crops. Grass and Forage Science, 18(2), 104-111. doi: 10.1111/j.1365-2494. 1963.tb00335.x

Van Soest, P. J., Robertson, J. B., \& Lewis, E. B. A. (1991). Methods for dietary fiber, neutral detergent fiber, and nonstarch polysaccharides in relation to animal nutrition. Journal of Dairy Science, 74(10), 3583-3597. doi: 10.3168/jds.S0022-03 02(91)78551-2

Volenec, J. J., \& Nelson, C. J. (2003). Environmental aspects of forage management. In: R. F. Burnes, C. J. Nelson, M. Collins, \& K. J. Moore (Eds.), Forages: an introduction to grassland agriculture (pp. 99-124). Ames: Blackwell.

Wilson, J. R. (1996). Shade-stimulated growth and nitrogen uptake by pasture grasses in a subtropical environment. Australian Journal of Agricultural Research, 47(7), 1075-1093. doi: 10.1071/AR9961075

Wirsenius, S., Azar, C., \& Berndes, G., (2010). How much land is needed for global food production under scenarios of dietary chances and livestock productivity increases in 2030? Agricultural Systems, 103(9), 621-638. doi: 10.1016/j.agsy.20 10.07.005 